УДК: $7.034 \ldots 7$

ББК: $85.103(4) 5$

A43

DOI: $10.18688 / \mathrm{aa} 188-8-69$

Eugenia Drakopoulou

\title{
The Revivification of Baroque Paintings in the Novels of Jorge Semprun
}

Jorge Semprun, a Spanish writer, who was politically active and passed away five years ago, included in his literary works several references to modern European history, which he inextricably linked with the art of painting, particularly that of the Baroque era.

He explains his personal involvement with European history as follows: ...I was born in Spain in 1923, so I was 12 years old when the Civil War broke out. By the end of the war, in 1939, I was living in exile, as my father, a liberal catholic, had chosen the Republican side and not Franco's Nationalists. As a philosophy student I joined the French Resistance. Had I been born a couple of years earlier, or later, my life would have been completely different. I was shaped by the historical circumstances. I belong to the generation that became 20 years old in 1943, when the battle of Stalingrad took place [26, p.44]. More specifically, both Semprun's family tradition and his own activities have a common feature: the involvement with public matters and the historical developments of the $20^{\text {th }}$ century. He was the grandson of Antonio Maura, who served as Prime Minister during the first two decades of the $20^{\text {th }}$ century in King Alfonso XIII's governments, the son of the democrat jurist and diplomat Hose Maria Semprun, self-exiled to France during the Spanish Civil War (1936-1939), a Doctor of Philosophy at Sorbonne, a member of the French Resistance, a prisoner in Buchenwald as a communist between 1943-1945, a member of the outlawed Communist Party of Spain (1945-1965), and Minister of Culture in Gonzalez's socialist governments in Spain (12/7/1988-12/3/1991) [5, p.4-11].

Semprun was a prolific writer. In his twenty three long novels [5, p.11-19], the role of memory is dominant while his stories have autobiographical elements [25]. Painting plays an important role in his work too, and his approach to baroque paintings, depending on the location of the paintings, is multi-faceted and ambiguous-aesthetic, autobiographical, historical and political $[12 ; 14]$. The interest in the attitude of the knowledgeable visitor and in the ideal way of exhibiting the paintings come back constantly in most of his works ${ }^{1}$.

The Museum, the location of the paintings, was an emblematic and privileged space in the writer's universe, a space pointing to the association of the autobiographical material with the fictional elements of the narrative. The Museum takes the place of a temple in his stories, not unlike its ancient function as a temple dedicated to the Muses. For example, this is vividly demonstrated in the description of the Hague's Parkstraat and the comment that the catholic church was situated halfway between the square where the Spanish Delegation was housed and

It is noted that this paper deals with three Jorge Sempruns' books: [17; 19;21]. 
the Mauritshuis museum. The writer recounts: "But I didn't go to church on Sunday. Neither on any other day. I frequently went to the Mauritshuis, home to Vermeer and Fabritius, but not to Parkstraat's church" [20, p. 18]. It is almost as if the Museum had taken the place of the church for a Spanish Catholic.

The Prado $^{2}$ was his primary museum space due to his personal experiences. Firstly, because of his frequent visits there as a young boy, before 1935, accompanied by his father [19, p. 195], and, secondly, because of the many hours he chose to spend there during the years of his illegal communist activity in Madrid during the 1950s [19, pp. 198-199].

The emblematic painting in Prado museum, Velasquez's work "Las Meninas", plays a central role in most of the works of the writer. The first "revivification", the moving of the work from Phillip IV's court in Madrid to its modern context, is mainly about the way in which Velasquez involves the onlooker as a reviewer in the painting's story. Semprun underlines the humanistic nature of the work, attributing it to the important role given to the human being as viewer. On another level, this is in agreement with the writer's view of the human being as the subject of history. In other words, Semprun models his use of paintings in his writings on Velasquez's inspiring self-inclusion as the painter in "Las Meninas" [6]. The painting is, thus, a centrepiece, due to its involvement in the discussion between the artist, the historical context and the viewer, a discussion with eternity itself.

With respect to the exhibition of the painting, Semprun was enthusiastic and keen on discovering a simple way of displaying it during the 1950s. The room where "Las Meninas" was exhibited in the Prado contained a large mirror which allowed visitors to view the work from multiple perspectives, and, therefore, to see themselves inside the painting too. That room in the Prado was prepared exclusively to house this painting. The mirror's surface allowed it to imitate the play of optical angles, initiated by the painting itself, in a way that is as evident as it is enigmatic [19, pp. 198-199].

In 1998, when Semprun became Spain's Minister of Culture, the Prado museum, as expected, was found again at the centre of his attention. More specifically, the way of displaying Velasquez's and Goya's works, as well as the exiled "Guernica", were among his main preoccupations.

The long conversations about the return of "Guernica", the best known $20^{\text {th }}$ century work of art, to Spain and about Picasso's wish - which the painter himself shared with Semprun in 1961 in California [19, p. 189] - to exhibit "Guernica" in the Prado, led the minister-writer to believe that artists do not care about where they will be buried but about where their works will be exhibited. He adopts André Malraux's idea of an Imaginary Museum [19, p. 189; 2]: "Art has obviously not turned into religion, but it has turned into faith. The sacredness of painting is not the sacredness of the gods any longer, but the sacredness of the dead. Cézanne and Van Gogh care a lot more about having their paintings exhibited in the Louvre than having their bodies buried in Christian soil. The sacred land for Cézanne, Van Gogh, Degas, Matisse and Braque is the Louvre" [19, p. 189]. For Picasso, it is the Prado. For Semprun, the Prado is an ideal place for the juxtaposition of painters; this was, for him, the basis of Picasso's wish to have the "Guernica"

\footnotetext{
2 https://www.museodelprado.es (accessed 22 February 2017).

3 https://www.museodelprado.es/en/the-collection/art-work/las-meninas/9fdc7800-9ade-48b0-ab8bedee94ea877f (accessed 22 February 2017).
} 
exhibited there. He explains that Picasso wanted to be in the Prado so that his paintings would be next to Velasquez's and Goyas, and so that people could see where he came from, from which tradition. He underlines characteristically: "It was not for fun, nor games, that Picasso made 83 variations of Velasquez's 'Las Meninas'. That artistic obsession bore high stakes" [19, p. 189].

Thus, for the Spanish Minister of Culture, the ideal way of exhibiting paintings in the museum is to create the sense of a certain juxtaposition of the painters. Semprun dreams about materializing the confrontation between Goya, Velasquez and Picasso. So, he proposed the juxtaposition inside the Prado of the three great Spanish painters and the way they conceived and rendered in their paintings three historic milestones of the country: Velasquez's "Surrender of Breda" (1634-1635), a city in the southern part of the Netherlands that was surrendered to the Spanish by the Dutch General while the defeated army pulled out with dignity, depicts the moment when the city key is handed over on $5^{\text {th }}$ June 1625 , a scene full of humanity as opposed to the horror of the war ${ }^{4}$ [1]; Goyas " 3 May 1808", which depicts the execution of the Spanish patriots by the French powers on the hill of Principe Pio of Madrid, and in which the scream, the desperation and the barbarity of the war are visually portrayed ${ }^{5}$ [9]; and Picasso's "Guernica", painted after April 1937, when the holy Basque town was totally destroyed in just three and a half hours by the Falangist forces, the Spanish, Italian and German troops under German command. "Guernica" was transformed into a symbol of modern total warfare and became synonymous with the horrors of the civil war $^{6}[23]$.

The exhibition of those three brilliant works about Man and War, dating from the beginning of the $17^{\text {th }}$ century to the $19^{\text {th }}$ and the $20^{\text {th }}$ centuries, was a way by means of which the Minister of Spain wished to implement a conversation between the creators, the works and the contemporary viewer of the Prado museum. This was another way of stating that there are cases where art and politics must be regarded as inseparable.

In the Hague, in Mauritshuis ${ }^{7}$, Semprun's involvement with the paintings of Vermeer and Fabritius, from the golden era of Dutch painting [13, sparsim], produced another kind of writing which could be named "Ekphrasis", an aesthetic description of a work of art combined, however, with a reflection on man, life and death through visual representations.

The experiential relation of Semprun with Mauritshaus, as mentioned earlier, began from his years of adolescence in the Hague, where Semprun's family first settled after leaving Madrid during the mid-1930s. Semprun's commentary, in his book La Deuxième Mort de Ramon Mercader [17], on Vermeer's and Karel Fabritius' paintings exhibited there takes us to another level, from the dialogue between painters to the dialogue between the works of art and the knowledgeable spectator.

From a mainly historico-political perspective, the writer associates the presence of the Nieuwe Kerk in the "View of Delft" (c. 1660-1661) ${ }^{8}$ [24, p.72; 11, sparsim] with the Spanish

4 https://www.museodelprado.es/en/the-collection/art-work/the-surrender-of-breda/0cc7577a-51d9-44fdb4d5-4dba8d9cb13a (accessed 22 February 2017).

5 https://www.museodelprado.es/en/the-collection/art-work/the-3rd-of-may-1808-in-madrid-or-the-executions/5e177409-2993-4240-97fb-847a02c6496c (accessed 22 February 2017).

6 http://www.museoreinasofia.es/en/collection/artwork/guernica (accessed 22 February 2017).

7 https://www.mauritshuis.nl (accessed 22 February 2017).

8 https://www.mauritshuis.nl/en/explore/the-collection/artworks/view-of-delft-92 (accessed 22 February 2017). 
resistance against Franco. If it is true that Vermeer painted, in his "View of Delft", the Nieuwe Kerk bathed in unrealistic light because this church housed the mausoleum of William of Orange, a ruler respected for his heroic resistance to the Spanish rule, Semprun, an exiled Spaniard, who had the power of the observer, transfers the painting to his contemporary historical context and appropriates the same building as a symbol of resistance against the Spanish supporters of Franco.

But, more generally, the writer attempts a new, exceptionally modern way of "ekphrasis" concerning the 'View of Delft', describing it not only in words, as a continuation of "ut pittura poesis" [22], but enriching it with the dynamic presence of the museum's visitors, who see their lives take on new meaning as they become linked to the painting, as a result of the meditation on the location of the source of light in the painting. In this way, the "ekphrasis" for a painting becomes fiction.

The first pages of the novel La Deuxième Mort de Ramon Mercader, which refers to the Cold War and focuses on the life, death and character of a spy who was an art connoisseur, constitute a complete analysis of Vermeer's work [17, pp. 13-33] and is characteristic of the fact that the writer pursued the autonomous publication of this first part of the book and its translation into English [18].

A further aspect of the painting's reading is directly connected to Proust. It is known that the writer-hero in $A$ la recherche $d u$ temps perdu, when facing the absolute perfection of Vermeer's work "The View of Delft", feels that his life has been worthless and dies in front of the painting $[15 ; 10$, p. $234 ; 8]$. He conveys, therefore, the message that life is nothing and art is everything. For Semprun, the "View of Delft" also functions as a microcosm of the artistic creation, a model for every work of art. The painting, for him, is a dominating world where harmony exists between the details and the whole. It is a masterful amalgam of composition, light, colour and mood, which offers a path for the eye to follow and to create a world that would rival reality rather than leading one to death, as Proust suggests [12, p. 172].

In Mauritshuis, after visiting the "View of Delft", Semprun pays tribute to the painting in the next room which he finds captivating and is related to Vermeer's Delft: Carel Fabritius' "The Goldfinch" $(1654)^{9}$ [11, pp. 260-263]. "The Goldfinch" is a chamber piece. A bird is sitting on its feeder, chained by its foot. In Fabritius' time, these birds were popular as pets. This is one of the few works we know by Fabritius because of the explosion of the gunpowder arsenal in Delft, which destroyed a large part of the town and in which the painter himself lost his life in October 1654. For the writer, the sad captive bird becomes the symbol of the destruction of the city and its painter. As the two paintings are exhibited in neighbouring rooms of Mauritshuis, the fact that Vermeer's "View of Delft", painted a few years after the explosion, shows no trace of the destruction leads to the conclusion that life has returned to normal. This message concludes the dialogue between the contemporary visitor to the Hague's Museum and the $17^{\text {th }}$ century Dutch paintings. Life finds a way back to normality, overcoming natural disasters and the personal defeats of artists and viewers.

9 https://www.mauritshuis.nl/en/discover/mauritshuis/masterpieces-from-the-mauritshuis/the-goldfinch-605 (accessed 22 February 2017). 
Following the Spanish and Dutch baroque painting, two paintings, which constitute variations on the same subject and were created in early $17^{\text {th }}$ century Rome and Florence, are at the center of Semprun's work. From Italy, where they were originally created, they are symbolically transferred by the writer to Catholic Spain and the Spanish civil war of the 1930s.

Written in Spanish in 2003, Semprun's book "Veinte años y un dia" [21; 16] starts with an "ekphrasis" of the panel 'Judith and Holofernes'. It is the first book of the writer, written in his mother tongue, and refers to the story of a family from Toledo, twenty years after the Spanish civil war had started, where Mercedes, a beautiful and enigmatic widow, is the central figure. The violent post-war Franco era is associated in the book with the biblical story of the beheading of the leader of the Assyrian people Holofernes by the beautiful Jewish widow, Judith. The beheading of Holofernes is the subject of many paintings and sculptures from the Renaissance and Baroque periods.

Artemisia Gentileschi painted twice the oft depicted biblical story. The first variation of the painting, exhibited today in Museum Capodimonte in Naples, was painted in Rome, where Gentileschi as a young woman was raped by a painter in her father's studio, an event which led to a notorious seventh-month trial in 1612 [3, Cat. n. 60]. The rape is frequently linked to her painting of Judith and is used to explain the cold and calculated violence this painting represents [4]. The Spanish Mercedes, central figure in Semprun's novel, encounters Gentileschi's paintings on her honeymoon trip in Naples. The view of the painting awakens her sexuality, which had been suppressed by the catechism of Catholic Spanish priests concerning the role of women in marriage. The heroine focuses more on the whiteness of Judith's shoulders, symbol of beauty, sensitivity and purity, despite the murderous act she committed. The blue dress, habitually the color of Virgin Mary's dress, stresses the purity of the central person of the painting. It is obvious that Semprun knows the comments of Garrand about the painting and its painter [7], and sees the painting as a model of female liberation, depicting a confrontation of the sexes from a female point of view. The Italian painter of the $17^{\text {th }}$ century is identified with the young Catholic Spanish woman of the $20^{\text {th }}$ century [12, pp. 177-179].

The second version of the painting, now in the Uffizi Gallery, was painted in Florence probably for Cosimo dei Medici and was completed around 1620 [3, Cat. n. 62]. In this version, Judith's face is more idealized and the scene is more theatrical, with blood spurting from Holofernes's neck. This associates it more closely in Semprun's novel with the Spanish Civil War. The adaptation of a biblical episode common in European culture, and the corollary association of Holofernes with the Ottoman danger, on the one hand, and of Judith with Christianity, on the other hand - let us recall Vivaldi's oratorio "Giuditha triumphans", which was commissioned to celebrate the victory of the Republic of Venice over the Ottomans during the siege of Corfu in 1716 - take on a new political dimension in Semprun's work. The scene is transformed into the vengeance of the losers of the Spanish Civil War on the winners. Furthermore, in Gentileschi's composition, the violent conflicts of lines and bodies, having as a central point the head of the dead Holofernes, are transformed through the story of the book into an image of Spain ravaged by Franco's presence.

All of the approaches to the paintings presented above and their multiple interpretations in Semprun's works suggest a revivification of the $17^{\text {th }}$ century paintings as they bring forward their relation to the contemporary spirit, the contemporary museum and the contemporary 
visitor. The main idea is that the painting is a historical object whose past must be related to the social and political conversation about the present.

\section{References}

1. Bailey A. Velázquez and The Surrender of Breda. New York, Henry Holt Publ., 2011. 288 p.

2. Céspedes Gallego J. André Malraux chez Jorge Semprún: l'héritage d'une quête, Revue André Malraux, n. 33. University of Oklahoma Publ., 2005, pp. 86-101 (in French).

3. Christiansen K.; Mann J. W. Orazio and Artemisia Gentileschi. New York, The Metropoliltan Museum of Art Publ.; New Haven; London, Yale University Press Publ., 2001. 476 p.

4. Contini R.; Solinas Fr. (eds). Artemisia, 1593-1654: pouvoir, gloire et passions d'une femme peintre, catalogue d'exposition. Paris, Gallimard Publ., 2012. 256 p. (in French).

5. Ferrán Of.; Herrmann G. Introduction. Ferrán Of.; Herrmann G. (eds.). A Critical Companion to Jorge Semprún. Buchenwald, Before and After. New York, Palgrave Macmillan Publ., 2014, pp. 1-36.

6. Finaldi G. Velázquez: Las Menínas. Scala Publishers Ltd, 2006. 8 p.

7. Garrand M.D. Artemisia Gentileschi: The Image of the Female Hero in Italian Baroque Art. Princeton, Princeton University Press Publ., 1989. 664 p.

8. Huyghe R.; O’Higgins J. Vermeer and Proust. Salmagundi, no.44/45, Vermeer (spring - summer 1979), pp. 78-88.

9. Hugh T. Goya: The Third of May 1808. London, The Penguin Press Publ., 1972. 112 p.

10. Karpeles E. Paintings in Proust: A Visual Companion to 'In Search of Lost Time'. London, Thames and Hudson Ltd Publ., 2008. 352 p.

11. Liedtke W. Vermeer and the Delft School. New York, The Metropolitan Museum of Art Publ.; New Haven and London, Yale University Press Publ., 2001. 626 p.

12. Miletić T. The Significance of Art in Semprun's Writing. Ferrán O. et al (eds.). A Critical Companion to Jorge Semprún, Buchenwald, Before and After. New York, Palgrave Macmillan Publ., 2014, pp. 169-184.

13. Noël M.-L. La peinture hollandaise du siècle d'or dans le roman: representations dans les literratures francaises et Anglophones. Paris, L'Harmattan Publ., 2009. 348 p. (in French).

14. Pedrol-Aquilà M. Présence nécessaire de l'art dans L'écriture ou la vie de Jorge Semprun. Cédille, Revista de Estudios Franceses, 2016, vol. 12, pp. 346-367 (in French).

15. Proust M. À la recherche du temps perdu, tome 5: La Prisonnière. Paris Gallimard Publ., 1989. 465 p. (in French).

16. Semilla Durán M. A. A Mirror of History: The Self and Its Reflections in Jorge Semprun's Oeuvre. Veinte a jos y un día: Duality and Vertigo. Ferrán Of.; Herrmann G. (eds.). A Critical Companion to Jorge Semprún, Buchenwald, Before and After. New York, Palgrave Macmillan Publ., 2014, pp. 155-168.

17. Semprun J. La deuxième mort du Ramon Mercader. Paris, Gallimard Publ., 1969. 432 p. (in French).

18. Semprun J.; Ortzen L. The View of Delft (a fiction). Salmagundi, no.44/45, Vermeer (spring - summer 1979), pp. 49-62.

19. Semprun J. Federico Sanchez vous salue bien. Paris, Grasset et Fasquelle Publ., 1993. 333 p. (in French).

20. Semprun J. Adieu, vive clarté. Paris, Gallimard Publ., 1998. 249 p. (in French).

21. Semprun J. Vingt ans et un jour. Paris, Gallimard Publ., 2004. 304 p. (in French).

22. Vouilloux B. La peinture dans le texte, XVIIIe - XXe siècles. Paris, CNRS Publ., 2000. 135 p. (in French).

23. Warnke C.-P. War, Art and "Guernica". Walther I. F. (ed.). Pablo Picasso 1881-1973, part 2. Taschen Publ., 2007, pp. 387-401.

24. Wheelock K. A. Vermeer: The Complete Works. New York, Harry N. Abrams Publ., 1997. 72 p.

25. Quilez Esteve L.; Ramos Munté R. A. Autobiography and Fiction in Semprún's Texts. CLCWeb: Comparative Literature and Culture, vol. 11, no. 1, March 2009, pp. 1-8.

26. The Book's Journal, Interview, no. 9, July 2011, pp. 42-45 Available at booksjournal.gr/component/k2/ item/317-319 (accessed 22 February 2017) (in Greek).

Title. The Revivification of Baroque Paintings in the Novels of Jorge Semprun.

Author. Eugenia Drakopoulou - archeologist, art historian, research director. Institute of Historical Research, National Hellenic Research Foundation, 48 Vassileos Constantinou Avenue 11635, Athens, Greece. egidrak@eie.gr 
Abstract. Jorge Semprun (1923-2011) was a Spanish, politically active writer who lived in France most of his life. He served as Minister of Culture in Spain's socialist government from 1988 to 1991. During the period of his office a subject of prime importance was the action of exposing paintings in a modern museum in order to encourage the dialogues between the artists of several periods and mainly the dialogue of modern public with the artistic heritage of the past. His interest, manifested in the extensive and recurring references, made in his works, to three paintings from $17^{\text {th }}$ century Holland, Italy and Spain, lies mainly in the renovation, the new life that he attributes to them by integrating baroque works in the history of modern Europe. Three famous paintings, Johannes Vermeer's "View of Delft", the "Judith slaying Holofernes's" of Artemisia Gentileschi and Diego Velasquez's "Las Meninas" find a new place in history of art as their initial "life" in Delft, Rome and Madrid respectively is imbricated, on multiple levels, with persons and events of the contemporary era. Further, the views of the writer that he was, on ways to exhibit baroque works in today's museums, heightened by his sensitivities as a citizen of Europe and by a sense of responsibility owing to his institutional position as minister of culture in Spain, greatly contribute to the actual debate on the interaction between the $21^{\text {st }}$ and the $17^{\text {th }}$ century.

Keywords: Semprun; baroque painting; Vermeer; Velasquez; Artemisia Gentileschi; Prado; Spain.

Название статьи. «Обновление» живописи барокко в книгах Хорхе Семпруна.

Сведения об авторе. Дракопулу Евгения - археолог, искусствовед, директор Института исторических исследований. Греческий национальный фонд научных исследований, ул. Басилеос Константину, 48, 11635, Афины, Греция. egidrak@eie.gr

Аннотация. Хорхе Семпрун (1923-2011) был испанским писателем, публицистом и общественным деятелем, большую часть жизни прожившим во Франции. Он занимал пост министра культуры в социалистическом правительстве Испании с 1988 по 1991 г. Будучи министром, особое значение придавал экспонированию произведений живописи в современном музее, считая необходимым установление своеобразного творческого диалога между художниками разных эпох, но главное - между современным зрителем и художественным наследием прошлого. Свой интерес к такому взаимодействию, неоднократно продемонстрированный в его работах посредством обращения к произведениям голландской, итальянской и испанской живописи XVII в., выразился в том, что автор как бы вдыхает в них новую жизнь, вводя барочные произведения в исторический контекст современной Европы. Речь идет о трех знаменитых полотнах - «Вид города Делфта» Яна Вермеера, «Юдифь, обезглавливающая Олоферна» Артемизии Джентилески и «Менины» Диего Веласкеса, которые волей автора обретают новое место в истории искусства, а их первоначальная «жизнь» в Делфте, Риме и Мадриде соответственно на разных уровнях накладывается на судьбы людей и события наших дней. Помимо прочего, взгляды Семпруна-писателя на то, как следует представлять искусство барокко в современном музее, имели дополнительное высокое звучание, вдохновленное его гражданскими чувствами европейца, и ответственностью, лежавшей на нем как на министре культуры Испании. Суждения Семпруна вносят несомненный вклад в современную дискуссию о культурном взаимодействии XXI и XVII вв.

Ключевые слова: Хорхе Семпрун; живопись барокко; Ян Вермеер; Диего Веласкес; Артемизия Джентилески; Прадо; Испания. 